\title{
Paucibacter toxinivorans gen. nov., sp. nov., a bacterium that degrades cyclic cyanobacterial hepatotoxins microcystins and nodularin
}

Correspondence
Jarkko Rapala
jarkko.rapala@sttv.fi

\author{
Jarkko Rapala, ${ }^{1} \dagger$ Katri A. Berg, ${ }^{1}$ Christina Lyra, ${ }^{1}$ R. Maarit Niemi, ${ }^{1}$ \\ Werner Manz, ${ }^{2} \ddagger$ Sini Suomalainen, ${ }^{3}$ Lars Paulin $^{3}$ and Kirsti Lahti ${ }^{1} \S$ \\ ${ }^{1}$ Finnish Environment Institute, PO Box 140, FIN-00251 Helsinki, Finland \\ ${ }^{2}$ Fachgebiet Ökologie der Mikroorganismen, Institut für Technischen Umweltschutz, Technische \\ Universität Berlin, D-10587 Berlin, Germany \\ ${ }^{3}$ Institute of Biotechnology, PO Box 56, FIN-00014 University of Helsinki, Finland
}

Thirteen bacterial isolates from lake sediment, capable of degrading cyanobacterial hepatotoxins microcystins and nodularin, were characterized by phenotypic, genetic and genomic approaches. Cells of these isolates were Gram-negative, motile by means of a single polar flagellum, oxidase-positive, weakly catalase-positive and rod-shaped. According to phenotypic characteristics (carbon utilization, fatty acid and enzyme activity profiles), the $\mathrm{G}+\mathrm{C}$ content of the genomic DNA (66.1-68.0 mol\%) and 16S rRNA gene sequence analysis (98.9-100\% similarity) the strains formed a single microdiverse genospecies that was most closely related to Roseateles depolymerans (95.7-96.3\% 16S rRNA gene sequence similarity). The isolates assimilated only a few carbon sources. Of the 96 carbon sources tested, Tween 40 was the only one used by all strains. The strains were able to mineralize phosphorus from organic compounds, and they had strong leucine arylamidase and chymotrypsin activities. The cellular fatty acids identified from all strains were $\mathrm{C}_{16: 0}(9 \cdot 8-19 \%)$ and $\mathrm{C}_{17: 1} \omega 7 c(<1-5 \cdot 8 \%)$. The other predominant fatty acids comprised three groups: summed feature $3(<1-2 \cdot 2 \%)$, which included $\mathrm{C}_{14: 0} 3-\mathrm{OH}$ and $\mathrm{C}_{16: 1}$ iso $\mathrm{I}$, summed feature 4 (54-62\%), which included $\mathrm{C}_{16: 1} \omega 7 \mathrm{c}$ and $\mathrm{C}_{15: 0}$ iso $\mathrm{OH}$, and summed feature 7 (8.5-28\%), which included $\omega 7 c, \omega 9 c$ and $\omega 12 t$ forms of $\mathrm{C}_{18: 1}$. A more detailed analysis of two strains indicated that $\mathrm{C}_{16: 1} \omega 7 \mathrm{c}$ was the main fatty acid. The phylogenetic and phenotypic features separating our strains from recognized bacteria support the creation of a novel genus and species, for which the name Paucibacter toxinivorans gen. nov., sp. nov. is proposed. The type strain is $2 \mathrm{C}^{2} \mathrm{O}^{\top}\left(=\mathrm{DSM} 16998^{\top}=\mathrm{HAMBI} 2767^{\top}=\mathrm{VYH} 193597^{\top}\right)$.
Published online ahead of print on 14 March 2005 as DOI 10.1099/ ijs.0.63599-0.

†Present address: National Product Control Agency for Welfare and Health, PO Box 210, FIN-00531 Helsinki, Finland.

‡Present address: Bundesanstalt für Gewässerkunde, Postfach 2002 53, D-56002 Koblenz, Germany.

§Present address: The Water Protection Association of the River Vantaa and Helsinki Region, Asemapäällikönkatu 12 C, FIN-00520 Helsinki, Finland.

Abbreviations: $\mathrm{BChl} a$, bacteriochlorophyll a; MP, maximum parsimony; $\mathrm{NJ}$, neighbour joining; $\mathrm{PHC}$, poly(hexamethylene carbonate).

The GenBank/EMBL/DDBJ accession numbers for the 16S rRNA gene sequences of strains 15B, 2, 2B15, 2B17, 2B3, S1030, G44, F39, F36, 7A, 2C23, 2C20 ${ }^{\top}$ and 2B5 are AY515379-AY515391, respectively.

Physiological characteristics and whole-cell fatty acid profiles of the strains investigated here are detailed in supplementary tables available in IJSEM Online.
Hepatotoxic microcystins and nodularin belong to the large group of bioactive peptides produced by cyanobacteria. In dense accumulations of cyanobacteria in water, very high concentrations (up to $25 \mathrm{mg} \mathrm{l}^{-1}$ ) of these toxins have been reported (Sivonen \& Jones, 1999). Microcystins and nodularin are considered to be relatively resistant to degradation owing to their ring structure and to the presence of several unusual amino acids in the molecule. Indications of bacteria that degrade microcystins have been reported from sewage effluent, lake and river water, lake sediments and infiltration soil areas of lake water (Sivonen \& Jones, 1999; Holst et al., 2003), but only a few bacterial strains with degradative ability towards microcystins have been isolated. Jones et al. (1994), Park et al. (2001), Saito et al. (2003) and Ishii et al. (2004) described the isolation of four Sphingomonas sp. or sphingomonad-like strains that degraded microcystins. Lahti et al. (1998) isolated 17 bacterial strains capable of degrading microcystins. 
Degradation of nodularin was tested with three of these strains, and they all degraded this toxin. The strains were isolated from sediment (16 strains) and water (one strain) of eutrophic lakes Tuusulanjärvi (15 strains) and Vihnusjärvi (two strains), southern Finland, on $10 \%(\mathrm{v} / \mathrm{v}) \mathrm{Z} 8$ mineral medium supplemented with $1 \cdot 2 \%$ agar (Difco) and solidphase fractionated extract of microcystins $\left(8 \mathrm{mg} \mathrm{l}^{-1}\right)$. The cultures were stored at $-80{ }^{\circ} \mathrm{C}$ in skimmed milk tubes $(20 \mathrm{~g}$ skimmed milk, LabM MC 27, in $100 \mathrm{ml}$ deionized water, sterilized at $115^{\circ} \mathrm{C}$ for $\left.10 \mathrm{~min}\right)$. The strains were strictly aerobic, and they were routinely grown on R2A plates or in liquid R2 medium. They grew well at $20-30^{\circ} \mathrm{C}$, but failed to grow at $37^{\circ} \mathrm{C}$ and on rich growth media such as trypticase soy agar (TSA; Difco). On the basis of whole-cell fatty acid profiles and partial 16S rRNA gene sequencing (500 bp) Lahti et al. (1998) tentatively identified one of the 17 strains as a Sphingomonas sp. strain, but the two other strains investigated could only be classified as members of the $\beta$ Proteobacteria.

Thirteen of these 17 microcystin-degrading strains were characterized in this study. Cells were observed under a phase-contrast light microscope (Diaplan, DMRXA2; Leica) at $1000 \times$. Gram-staining of the cells was performed according to Hucker (Murray, 1981). The motility of the strains was studied on casitone-yeast extract agar according to Ward et al. (1986) using incubation for 7 days at $30^{\circ} \mathrm{C}$. Flagella were observed from silver-nitrate-stained cells of strain $2 \mathrm{C} 20^{\mathrm{T}}$ that were grown for $44 \pm 4 \mathrm{~h}$ at $20 \pm 2{ }^{\circ} \mathrm{C}$ on R2A slants overlaid with sterile deionized water. After cultivation, the water was collected from the surface of the slants and left to stand at $20 \pm 2{ }^{\circ} \mathrm{C}$ for $2 \mathrm{~h}$ before staining. Oxidase and catalase tests were performed according to standard methods (APHA, 1985). The presence of bacteriochlorophyll $a$ (BChl $a$ ) was examined from the cells of strain $2 \mathrm{C} 20^{\mathrm{T}}$ grown on R2A plates for $68 \pm 4 \mathrm{~h}$ at $20 \pm 2{ }^{\circ} \mathrm{C}$ in the dark. Absorption spectra (340-1100 nm) were recorded spectrophotometrically (Hitachi U-2000) from intact cells suspended in sucrose solution (5 $\mathrm{g}$ sucrose in $3.5 \mathrm{ml}$ deionized water) and acetone extract of the cells. Cells were Gram-negative, oxidase-positive rods $(0 \cdot 5-0 \cdot 7 \times 1 \cdot 3-5 \cdot 0 \mu \mathrm{m})$ and motile by means of a single polar flagellum. Cells were weakly catalase-positive when tested with a $3 \%$ oxygen peroxidase solution. When grown on $\mathrm{R} 2 \mathrm{~A}$ plates at $20 \pm 2{ }^{\circ} \mathrm{C}$ for $68 \pm 4 \mathrm{~h}$ they formed greyish colonies with a maximum size of $1 \mathrm{~mm}$, and no BChl $a$ was observed.

Physiological characteristics of the strains were studied using API 20NE and API ZYM tests (bioMérieux) and GN MicroPlate tests (Biolog Inc.). The sensitive fluorogenic test kit (Vepsäläinen et al., 2001) utilizing substrate analogues labelled with 4-methylumbelliferone compounds was used for the measurement of 12 enzyme activities (arylsulphatase, phosphomonoesterase, phosphodiesterase, cellobiosidase, $\alpha$ - and $\beta$-glucosidase, $\beta$-xylosidase, chitinase, lipase, esterase, $\beta$-glucuronidase and $\alpha$-galactosidase). For the API tests the strains were grown on R2A plates (Difco) at $20 \pm 2{ }^{\circ} \mathrm{C}$ for
3-4 days. The API 20NE test strips were incubated at room temperature for 4 and 7 days, and the API ZYM strips at $20 \pm 2{ }^{\circ} \mathrm{C}$ for $20 \mathrm{~h}$. For the GN MicroPlate tests the strains were grown on R2A plates for $68 \pm 4 \mathrm{~h}$. The GN plates were incubated at $30 \pm 2^{\circ} \mathrm{C}$ for $21 \pm 3 \mathrm{~h}$. Because the growth of all strains was poor after incubation for $24 \mathrm{~h}$ (the normal incubation period), the incubation time was extended and the results recorded also after incubation for $96 \pm 4 \mathrm{~h}$. For fluorogenic detection of enzyme activities the strains were cultivated in liquid $\mathrm{R} 2$ medium at $20 \pm 2{ }^{\circ} \mathrm{C}$ overnight, the cultures were diluted $(50: 50)$ with modified universal buffer (MUB; Tabatabai, 1994) at pH 7 and $200 \mu \mathrm{l}$ of the mixtures was added in duplicates on the substrates into the wells of the microtitre plates. The fluorescence $\left(\lambda_{\text {excitation }}\right.$ $355 \mathrm{~nm}, \lambda_{\text {emission }} 460 \mathrm{~nm}$ ) was recorded with a plate reader (Wallac 1420 multilabel counter) immediately after addition $(0 \mathrm{~h})$ and after incubation for $3 \mathrm{~h}$ at $20 \pm 2{ }^{\circ} \mathrm{C}$. The final results were obtained by subtracting values recorded at $0 \mathrm{~h}$ from those recorded at $3 \mathrm{~h}$. Enzyme activities and carbon utilization of the strains are given in Supplementary Tables S1 and S2 available in IJSEM Online.

According to their enzyme activities (Supplementary Table S1) all strains had a limited potential to use macromolecules common in the environment as sources of carbon and sulphur, but had a high potential to mineralize organic phosphorous compounds. Activities of arylamidases and chymotrypsin were high or very high, indicating that the strains were able to cleave amino acid residues from organic compounds, and to hydrolyse these amino acids further. All strains gave positive reactions for alkaline and acid phosphatases, naphthol-AS-BI-phosphohydrolase and phosphodiesterase. Phosphomonoesterase and $\beta$ glucosidase activities were common among the strains tested, but no arylsulphatase, cellobiosidase, $\alpha$-glucosidase, $\beta$-xylosidase, chitinase or $\alpha$-galactosidase activities were detected. Thus, the strains were efficient in mineralization of phosphorus and could release glucose by cutting sugar monomers from cellulose, but could not release D-xylose from 1,4- $\beta$-D-xylane, degrade cellobiose by hydrolysis of $1,4-\beta$-D-glucoside bonds, release sugar monomers from starch or glycogen, release sulphur from organic molecules or degrade chitin, galactose oligosaccharides, galactomannans or galactolipids. Two strains (S1030 and 7A; Supplementary Table S1) had $\beta$-glucuronidase activity, which is used as a specific detection test at elevated temperatures for Escherichia coli in water samples (Sartory \& Howard, 1992).

Some discrepancies were detected in the results of the enzyme activities measured with different methods. The strains had weak esterase and lipase activities in the API tests, but in the more sensitive fluorogenic tests these activities were strong. Fluorogenic analysis yielded positive reactions for $\beta$-glucosidase, and hydrolysis of aesculin (i.e. $\beta$-glucosidase activity) was observed in the API 20NE tests but not in the API ZYM test strips. $\beta$-Galactosidase activity was observed in most of the strains in the API 20NE tests 
but not with the API ZYM test strips. Activity of $\beta$ glucuronidase was detected in strains S1030 and 7A with the fluorogenic substrate analogues but not in the API tests. It is probable that the generally higher activities in the measurements based on fluorescence were due to the higher sensitivity of the fluorogenic method and possibly to differences in $\mathrm{pH}$ and the substrate used in the tests. Chemical degradation of the fluorogenic substrates was not observed, because in the buffered sterile control media the increase in absorbance was insignificant compared with that in the bacterial cultures.

The isolates used a limited number of carbon sources. Maltose and gluconate were the only carbon sources that most of the isolates assimilated in the API tests (Supplementary Table S1). In the Biolog tests, after incubation for $21 \pm 3 \mathrm{~h}$, all the strains showed the ability to use Tween 40 as a carbon source. Six strains $(2 \mathrm{C} 23,2 \mathrm{~B} 3,2 \mathrm{~B} 15,2 \mathrm{~B} 5$, $15 \mathrm{~B}$ and 2) were also able to use $\beta$-hydroxybutyric acid. Additionally, strain 2B15 used DL-lactic acid and $p$ hydroxyphenylacetic acid, and strain 2 used DL-lactic acid and $\gamma$-hydroxybutyric acid. Even after incubation for $96 \pm 4 \mathrm{~h}$ (Supplementary Table S2) clearly positive reactions of all strains were detected only with Tween 40 .

For whole-cell fatty acid analysis the strains were cultivated on $50 \%$ TSA plates (Difco) at $20 \pm 2{ }^{\circ} \mathrm{C}$ for $68 \pm 4 \mathrm{~h}$. The fatty acid composition was analysed as methyl esters by GLC as described by Nohynek et al. (1993). Two strains were also analysed at the Deutsche Sammlung von Mikroorganismen und Zellkulturen GmbH (DSMZ). Cellular fatty acids identified from all strains were $C_{16: 0}(9 \cdot 8-19 \%)$ and $\mathrm{C}_{17: 1} \omega 6 c(<1-5 \cdot 8 \%) \quad$ (Supplementary Table S3). The other predominant fatty acids fell into three groups: summed feature $3(<1-2 \cdot 2 \%)$, which included $\mathrm{C}_{14: 0} 3$ $\mathrm{OH}$ and $\mathrm{C}_{16: 1}$ ISO I, summed feature 4 (54-62\%), which included $\mathrm{C}_{16: 1} \omega 7 c$ and $\mathrm{C}_{15: 0}$ ISO OH, and summed feature $7(8 \cdot 0-28 \%)$, which included $\omega 7 c, \omega 9 c$ and $\omega 12 t$ forms of $\mathrm{C}_{18: 1}$. A more detailed analysis of two strains (F36 and G44) indicated that $\mathrm{C}_{16: 1} \omega 7 c$ was the main fatty acid.

Genomic DNA was isolated from the strains using the commercial RDtract DNA-RNA purification kit (BioLabs). The 16S rRNA genes were sequenced with the DNA cycle sequencing system (Promega) as described by Kalmbach et al. (1997). We used BLAST searches (Altschul et al., 1997) of the GenBank database for the sequences, and they were aligned using the BIOEDIT program. Datasets of $1430 \mathrm{bp}$ including gaps were analysed with PAUP ${ }^{*}$ (Swofford, 2001). Anabaena sp. 90 was used as an outgroup. Phylogenetic trees were inferred using neighbour-joining (NJ) and maximumparsimony (MP) criteria. The NJ tree was constructed on the basis of distance values calculated by the F84 model. In the MP criterion, 10 heuristic searches and random addition sequence starting trees were used. The validity of the groups was tested by analysing 1000 bootstrap replicates. The $\mathrm{G}+\mathrm{C}$ content of the genomic DNA was determined at the DSMZ by using HPLC (Mesbah et al., 1989). On the basis of the $16 \mathrm{~S}$ rRNA gene sequences all isolates were very similar to each other $(98 \cdot 9-100 \%)$. They formed five distinct sublineages with $\mathrm{G}+\mathrm{C}$ content varying from $66 \cdot 1$ to $68.0 \mathrm{~mol} \%$ (Supplementary Table S2). On the basis of 16S rRNA gene sequence analysis, the closest relatives of the strains were Roseateles depolymerans DSM 11814 and DSM $11813^{\mathrm{T}}$ (Suyama et al., 1999) with $95 \cdot 7-96 \cdot 3 \%$ similarity and 'Matsuebacter chitosanotabidus' 3001 (Park et al., 1999) with $96 \cdot 1-96 \cdot 8 \%$ similarity. The other seven closest relatives of the strains (Fig. 1) are poorly characterized, and they have been isolated from various sources. Whereas the two closest relatives, $\beta$-proteobacterial strains R-8875 (97.0$97 \cdot 1 \%$ similarity) and CD12 (96.5-96.8 \% similarity), were isolated from microbial mats of Antarctic lakes (van Trappen et al., 2002) and a cryoconite hole in Antarctica (Christner et al., 2003), Pseudomonas saccharophila DSM $654^{\mathrm{T}}(95 \cdot 4-96 \cdot 0 \%$ similarity) was isolated from ultrapure water in industrial systems (Kulakov et al., 2002), and the $\beta$-proteobacterial strain MBIC3293 (96.7-97.5\% similarity) from the surface of iron. Pseudomonas saccharophila is not included in the cluster of Pseudomonas (sensu stricto) and has been recommended to be transferred to another genus (Anzai et al., 2000). Strain MBIC3293 has tentatively been assigned as Leptothrix sp. (http://seasquirt.mbio.co.jp/ mbic/browse/bd_ccstrain.php?strainnumber $=3557)$, but

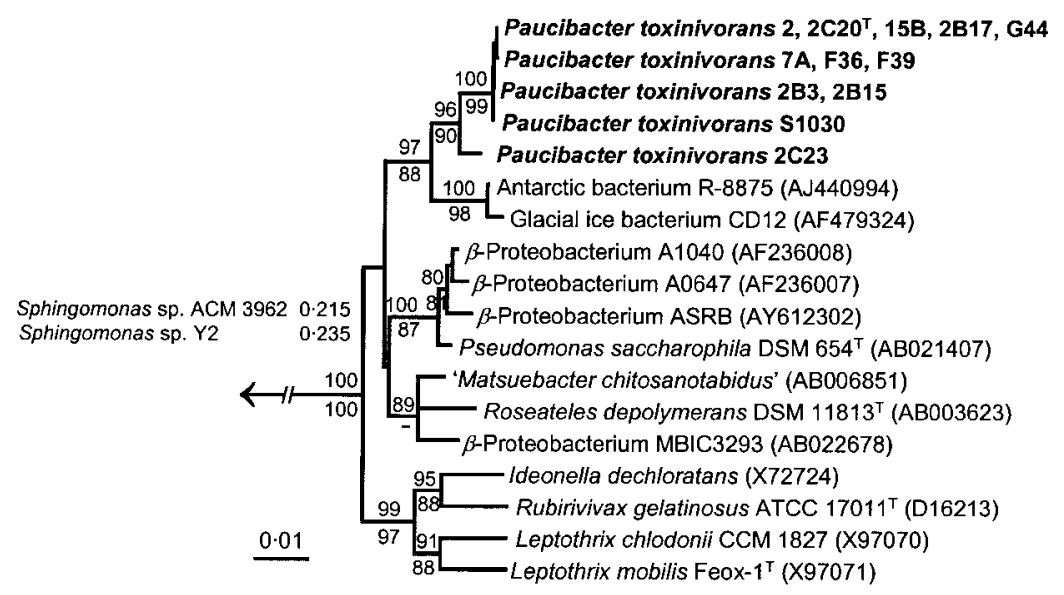

Fig. 1. Neighbour-joining tree based on 16S rRNA gene sequence analysis, illustrating the phylogenetic position of Paucibacter toxinivorans gen. nov., sp. nov. The most closely related $\beta$-proteobacterial strains and type strains of the most closely related species are included in the tree. Neighbourjoining and maximum-parsimony bootstrap values $(>80 \%)$ based on 1000 replicates are indicated at the nodes. The outgroup strains used were Sphingomonas sp. ACM 3962 (GenBank accession no. AF411072) and Y2 (AB084247) and Anabaena sp. 90 (AJ133156, not shown in the figure). 
according to our phylogenetic analysis the strain is closely related to Roseateles and 'Matsuebacter'. According to the information obtained from GenBank, the $\beta$-proteobacterial strain ASRB1 was isolated from fronds, and is resistant to arsenic. No information other than that for the 16S rRNA gene sequence from GenBank could be obtained for the unidentified $\beta$-proteobacterial strains A1040 and A0647.

The degradation ability of several isolates from different phylogenetic sublineages (strains S1030, F36, 2C20, 2 and $2 \mathrm{C} 23$ ) towards microcystins and nodularin was tested using extracts of toxic cyanobacterial strains obtained from the Finnish Environment Institute (Microcystis 764 producing microcystins -LR and -YR and Nodularia 790 producing nodularin). Previously, the degradation of nodularin had been preliminarily tested with two strains (G44 and F36) of the group, and degradation of microcystins had been studied using mainly one demethyl variant of microcystinRR (Lahti et al., 1998). The closest relative of the isolates, $R$. depolymerans DSM $11813^{\mathrm{T}}$, was also tested. All degradation tests were made in sterilized water that originated from an oligotrophic lake (Lake Päijänne). Toxin extracts from the cyanobacterial cells were partly purified using BondElut C18 cartridges (Varian) as described by Rapala et al. (2002), and were added (800-4300 $\left.\mu \mathrm{g} \mathrm{l}^{-1}\right)$ to the lake water. During the degradation tests, toxin concentrations were determined using the protein phosphatase inhibition assay (Rapala et al., 2002) and colony-forming unit counts were made after 7 days of incubation on R2A plates at $20 \pm 2{ }^{\circ} \mathrm{C}$.

All tested isolates degraded nodularin, with maximum rates of 35-87 $\mu \mathrm{g} \mathrm{l}^{-1} \mathrm{~h}^{-1}\left(3-560 \mathrm{fg}\right.$ cell $\left.{ }^{-1} \mathrm{~h}^{-1}\right)$, and the mixture of microcystins -LR and -YR, with maximum rates of 4-16 $\mu \mathrm{g} \mathrm{l}^{-1} \mathrm{~h}^{-1}$ (2-30 fg cell $\left.{ }^{-1} \mathrm{~h}^{-1}\right)$. R. depolymerans DSM $11813^{\mathrm{T}}$ did not degrade the toxins. Previously, only three of our isolates (strains G44 and F36 belonging to the $\beta$-Proteobacteria and the sphingomonad F38; Lahti et al., 1998) and the Sphingomonas sp. strain 7CY isolated in Japan (Ishii et al., 2004) have been reported to degrade nodularins. Strain 7CY degraded a variant of nodularin (nodularin-Har) only in the presence of microcystin-RR, whereas our strains degraded nodularin without addition of microcystin.

The closest relatives of our toxin-degrading isolates possess specific enzyme activities. $R$. depolymerans was originally isolated from river water as a degrader of poly(hexamethylene carbonate) (PHC) (Suyama et al., 1999). In addition to PHC the bacterium can utilize other biodegradable plastics. 'Matsuebacter chitosanotabidus' was characterized as a species producing the enzyme chitosanase, which catalyses the hydrolysis of glycosidic bonds of chitosan, a totally or partially deacetylated derivative of chitin (Park et al., 1999). The more distant Ideonella dechloratans is able to metabolize chlorate (Danielsson Thorell et al., 2003). From the same samples from Antarctica where CD12 was originally isolated, clones of cyanobacteria belonging to the genera Chamaesiphon, Leptolyngbya and Phormidium were sequenced and isolated. Because microcystins have been detected also from Antarctica (Hitzfeld et al., 2000), it would have been interesting to study the potential of CD12 to degrade microcystins. However, CD12 could not be obtained, and such tests could not be performed. Instead, some of the isolated Antarctic cyanobacterial strains were tested in our laboratory for the presence of microcystins, but none of the strains produced them (data not shown). Pseudomonas saccharophila is facultatively oligotrophic, and contains a nitrogen fixation gene nifH. The more distant Ideonella is also capable of fixing nitrogen (Elbeltagy et al., 2001). Similarly to these nitrogen-fixing bacteria, our strains preferred oligotrophic conditions, as they failed to grow on rich growth media, such as complete TSA (Lahti et al., 1998). Whether our strains possess nif genes and thus are capable of fixing nitrogen remains to be determined.

The bacteria characterized in this study could not be assigned to any recognized genus in the $\beta$-Proteobacteria. On the basis of the phylogenetic and physiological differences between the strains and their closest relative $R$. depolymerans, we propose the creation of a novel genus and species, Paucibacter toxinivorans gen. nov., sp. nov., to accommodate these strains. $R$. depolymerans and Paucibacter toxinivorans share $95 \cdot 7-96 \cdot 3 \%$ similarity based on $16 \mathrm{~S}$ rRNA gene sequence analysis. These two genera differ in their reactions in the catalase test, in the colour of their colonies (pink versus greyish), in the production of BChl $a$ and in the ability to utilize different carbon sources. Whereas $R$. depolymerans grows heterotrophically on several carbon sources commonly found in nature (glucose, fructose, galactose, sucrose, mannitol, acetate, citrate and succinate), Paucibacter toxinivorans was able to use only a few carbon sources. All 13 strains studied used Tween 40 and 11 strains $(85 \%)$ used $\beta$-hydroxybutyric acid. The other carbon sources that more than half of the strains used were maltose and gluconate. Additionally, $R$. depolymerans was not able to degrade cyanobacterial hepatotoxins microcystins and nodularin, whereas all Paucibacter toxinivorans strains did.

\section{Description of Paucibacter gen. nov.}

Paucibacter [Pau.ci.bac'ter. L. adj. paucus few/little; N.L. masc. n. bacter rod, N.L. masc. n. Paucibacter a rod that is content with a few (carbon sources)].

Cells are rod-shaped and motile by means of a single polar flagellum. Gram-negative, oxidase-, alkaline phosphatase-, chymotrypsin- and leucine arylamidase-positive. Weak catalase-positive reaction. Grow heterotrophically under aerobic conditions. Can grow using Tween 40 as a sole carbon source, but utilize few other carbon sources. The main cellular fatty acids are $\mathrm{C}_{16: 0}$, summed feature 4 $\left(\mathrm{C}_{16: 1} \omega 7 c\right)$ and summed feature $7(\omega 7 c, \omega 9 c$ and $\omega 12 t$ forms of $\left.C_{18: 1}\right) . G+C$ content of the genomic DNA is $66 \cdot 1-68 \cdot 0 \mathrm{~mol} \%$ (HPLC). The type species is Paucibacter toxinivorans. 


\section{Description of Paucibacter toxinivorans sp. nov.}

Paucibacter toxinivorans (to.xi.ni.vo'rans. N.L. n. toxinum toxin; L. part. adj. vorans devouring; N.L. part. adj. toxinivorans eating toxins, pertaining to its ability to degrade cyanobacterial hepatotoxins).

Displays the following properties in addition to those given in the genus description. Forms greyish colonies on R2A plates. After incubation for $65 \mathrm{~h}$ at $20 \pm 2{ }^{\circ} \mathrm{C}$ on $\mathrm{R} 2 \mathrm{~A}$, colonies are $\leqslant 1 \mathrm{~mm}$ in diameter. Cell size is $0 \cdot 5-0 \cdot 7 \times 1 \cdot 3-5 \cdot 0 \mu \mathrm{m}$. Fails to grow on rich media, such as TSA. Grows well at $20-30{ }^{\circ} \mathrm{C}$ but does not grow at $37^{\circ} \mathrm{C}$. Oxidase-positive. Weakly catalase-positive. Positive for acid and alkaline phosphatases, naphthol-AS-BIphosphohydrolase and phosphodiesterase. Most of the strains are positive for phosphomonoesterase. Positive for chymotrypsin, esterase, lipase esterase and leucine arylamidase. Most of the strains are positive for cysteine and valine arylamidases. Utilization of carbon sources other than Tween 40 is rare. Degrades microcystins and nodularin (cyanobacterial hepatotoxins). The main cellular fatty acids are $\mathrm{C}_{16: 0}(10-19 \%), \mathrm{C}_{16: 1} \omega 7 c$, which is included in summed feature $4(54-62 \%)$, and summed feature 7 $(8-28 \%)$, which includes $\omega 7 c, \omega 9 c$ and $\omega 12 t$ forms of $\mathrm{C}_{18: 1 .}$. G $+\mathrm{C}$ content of the genomic DNA is $66 \cdot 1-$ $68 \cdot 0 \mathrm{~mol} \%$ (HPLC).

The type strain is $2 \mathrm{C} 20^{\mathrm{T}}\left(=\mathrm{DSM} 16998^{\mathrm{T}}=\right.$ HAMBI $2767^{\mathrm{T}}$ $\left.=\mathrm{VYH} 193597^{\mathrm{T}}\right)$. DNA G $+\mathrm{C}$ content of the type strain is $66.9 \mathrm{~mol} \%$. Isolated from sediment of eutrophic lake Tuusulanjärvi, southern Finland.

\section{Acknowledgements}

The study was funded by the Academy of Finland, the Ministry of Environment and the Maj and Tor Nessling foundation. We thank Professor Hans G. Trüper for assistance with the etymology, and for naming of the isolates. We wish to thank Ms Minna Madsen, Ms Tuula Ollinkangas and Ms Mariliina Lifländer for technical assistance, Ms Kirsti Erkomaa for chemical expertise and Dr Maria Andersson (Helsinki University) for the fatty acid analyses. Dr Brent C. Christner (Montana State University) is acknowledged for information on the Antarctic bacterial isolate CD12, and Mr Brian H. Kvitko Jr (Ohio State University) for providing the cyanobacterial strains isolated from Antarctica.

\section{References}

Altschul, S. F., Madden, T. L., Schäffer, A. A., Zhang, J., Zhang, Z., Miller, W. \& Lipman, D. J. (1997). Gapped BLAST and PSI-BLAST: a new generation of protein database search programs. Nucleic Acids Res 25, 3389-3402.

Anzai, Y., Kim, H., Park, J. Y., Wakabayashi, H. \& Oyaizu, H. (2000). Phylogenetic affiliation of the pseudomonads based on 16S rRNA sequence. Int J Syst Evol Microbiol 50, 1563-1589.

APHA (1985). Standard Methods for the Examination of Water and Wastewater, 16th edn. Washington, DC: American Public Health Association.
Christner, B. C., Kvitko, B. H., II \& Reeve, J. N. (2003). Molecular identification of Bacteria and Eukarya inhabiting an Antarctic cryoconite hole. Extremophiles 7, 177-183.

Danielsson Thorell, H., Stenklo, K., Karlsson, J. \& Nilsson, T. (2003). A gene cluster for chlorate metabolism in Ideonella dechloratans. Appl Environ Microbiol 69, 5585-5592.

Elbeltagy, A., Nishioka, K., Sato, T., Suzuki, H., Ye, B., Hamada, T., Isawa, T., Mitsui, H. \& Minamisawa, K. (2001). Endophytic colonization and in planta nitrogen fixation by a Herbaspirillum sp. isolated from wild rice species. Appl Environ Microbiol 67, 5285-5293.

Hitzfeld, B. C., Lampert, C. S., Spaeth, N., Mountfort, D., Kaspar, H. \& Dietrich, D. R. (2000). Toxin production in cyanobacterial mats from ponds on the McMurdo ice shelf, Antarctica. Toxicon 38, 1731-1748.

Holst, T., Jørgensen, N. O. G., Jørgensen, C. \& Johansen, A. (2003). Degradation of microcystin in sediments at oxic and anoxic, denitrifying conditions. Water Res 37, 4748-4760.

Ishii, H., Nishijima, M. \& Abe, T. (2004). Characterization of degradation process of cyanobacterial hepatotoxins by a gramnegative aerobic bacterium. Water Res 38, 2667-2676.

Jones, G. J., Bourne, D. G., Blakeley, R. L. \& Doelle, H. (1994). Degradation of the cyanobacterial hepatotoxin microcystin by aquatic bacteria. Nat Toxins 2, 228-235.

Kalmbach, S., Manz, W. \& Szewzyk, U. (1997). Isolation of new bacterial species from drinking water biofilms and proof of their in situ dominance with highly specific $16 \mathrm{~S}$ rRNA probes. Appl Environ Microbiol 63, 4164-4170.

Kulakov, L. A., McAllister, M. B., Ogden, K. L., Larkin, M. J. \& O'Hanlon, J. F. (2002). Analysis of bacteria contaminating ultrapure water in industrial systems. Appl Environ Microbiol 68, 1548-1555.

Lahti, K., Niemi, R. M., Rapala, J. \& Sivonen, K. (1998). Biodegradation of cyanobacterial toxins - characterization of toxin degrading bacteria. In Harmful Algae. Proceedings of the VIII International Conference of Harmful Algae, pp. 363-365. Edited by B. Reguera, J. Blanco, M. L. Fernández \& T. Wyatt. Santiago de Compostela: Intergovernmental Oceanographic Commission of UNESCO.

Mesbah, M., Premachandran, U. \& Whitman, W. B. (1989). Precise measurement of the $\mathrm{G}+\mathrm{C}$ content of deoxyribonucleic acid by highperformance liquid chromatography. Int J Syst Bacteriol 39, 159-167.

Murray, R. G. E. (1981). Morphology. In Manual of Methods for General Bacteriology, Section 1, pp. 5-61. Edited by P. Gerhardt. Washington, DC: American Society for Microbiology.

Nohynek, L. J., Häggblom, M. M., Palleroni, N. J., Kronqvist, K., Nurmiaho-Lassila, E.-L. \& Salkinoja-Salonen, M. (1993). Characterization of a Mycobacterium fortuitum strain capable of degrading polychlorinated phenolic compounds. Syst Appl Microbiol 16, 126-134.

Park, J. K., Shimono, K., Ochiai, N., Shigeru, K., Kurita, M., Ohta, Y., Tanaka, K., Matsuda, H. \& Kawamukai, M. (1999). Purification, characterization, and gene analysis of a chitosanase (ChoA) from Matsuebacter chitosanotabidus 3001. J Bacteriol 181, 6642-6649.

Park, H.-D., Sasaki, Y., Maruyama, T., Yanagisawa, E., Hiraishi, A. \& Kato, K. (2001). Degradation of the cyanobacterial hepatotoxin microcystin by a new bacterium isolated from a hypertrophic lake. Environ Toxicol 16, 337-343.

Rapala, J., Erkomaa, K., Kukkonen, J., Sivonen, K. \& Lahti, K. (2002). Detection of microcystins with protein phosphatase inhibition assay, high-performance liquid chromatography-UV-detection and enzyme-linked immunosorbent assay. Comparison of methods. Anal Chim Acta 466, 213-231. 
Saito, T., Okano, K., Park, H.-D., Itayama, T., Inamori, Y., Neilan, B. A., Burns, B. P. \& Sugiura, N. (2003). Detection and sequencing of the microcystin LR-degrading gene, $m l r A$, from new bacteria isolated from Japanese lakes. FEMS Microbiol Lett 229, 271-276.

Sartory, D. P. \& Howard, L. (1992). A medium detecting $\beta$ glucuronidase for the simultaneous membrane filtration enumeration of Escherichia coli and coliforms from drinking water. Lett Appl Microbiol 15, 273-276.

Sivonen, K. \& Jones, G. (1999). Cyanobacterial toxins. In Toxic Cyanobacteria in Water. A Guide to Their Public Health Consequences, Monitoring and Management, pp. 41-111. Edited by I. Chorus \& J. Bartram. London: E \& FN Spon.

Suyama, T., Shigematsu, T., Takaichi, S., Nodasaka, Y., Fujikawa, S., Hosoya, H., Tokiwa, Y., Kanagawa, T. \& Hanada, S. (1999). Roseateles depolymerans gen. nov. sp. nov., a new bacteriochlorophyll $a$-containing obligate aerobe belonging to the $\beta$-subclass of the Proteobacteria. Int $J$ Syst Bacteriol 49, 449-457.
Swofford, D. L. (2001). PAUP*: Phylogenetic Analysis Using Parsimony *and Other Methods, version 4.0b8. Sunderland, MA: Sinauer Associates.

Tabatabai, M. A. (1994). Soil enzymes. In Methods of Soil Analysis, Part 2. Microbiological and Biochemical Properties, pp. 775-833. Edited by R. W. Weaver, S. Angle, P. Bottomley, D. Bezdicek, S. Smith, A. Tabatabai \& A. Wollum. Madison, WI: Soil Science Society of America.

van Trappen, S., Mergaert, J., Van Eygen, S., Dawyndt, P., Cnockaert, M. C. \& Swings, J. (2002). Diversity of 746 heterotrophic bacteria isolated from microbial mats from ten Antarctic lakes. Syst Appl Microbiol 25, 603-610.

Vepsäläinen, M., Kukkonen, S., Vestberg, M., Sirviö, H. \& Niemi, R. M. (2001). Application of soil enzyme activity test kit in a field experiment. Soil Biol Biochem 33, 1665-1672.

Ward, N. R., Wolfe, R. L., Justice, C. A. \& Olson, B. H. (1986). The identification of gram-negative, non-fermentative bacteria from water: problems and alternative approaches to identification. $A d v$ Appl Microbiol 31, 293-365. 